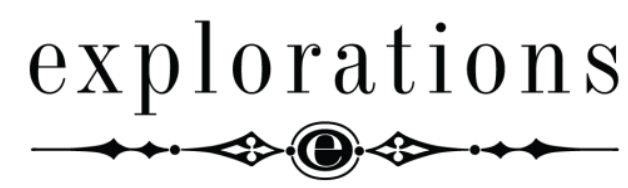

Explorations: A Journal of Language and Literature

\title{
INTERVIEW
}

\section{Elegy became our song}

Jacek Gutorow in conversation with Henri Cole

DOI: 10.25167/EXP13.17.5.1

Henri Cole was born in 1956 in Fukuoka, Japan, and raised in Virginia, in a house where French, Armenian and English were spoken. He received his BA at the college of William and Mary, his MA at the University of Wisconsin (Milwaukee), and his MFA at Columbia University. He debuted with The Marble Queen (1986) and has since published eight more volumes, including Pulitzer Prize finalist Middle Earth (2003), LA Times Book Prize finalist Pierce the Skin: Selected Poems 1982-2007 (2010) and, most recently, Nothing to Declare (2016). His awards and honors include the Kingsley Tufts Poetry Award, the Berlin Prize of the American Academy in Berlin, the Rome Prize in Literature from the Academy of Arts and Letters, and the Amy Lowell Travelling Scholarship. From 1982 to 1988 he served as the executive director of the Academy of American Poets. He has taught at Ohio State University, Harvard University and Yale University. He lives in Boston.

Cole's contemplative poems follow the meandering movements and stops of the perceptive mind. We will find in them traces leading back to such high modernist poets as Elizabeth Bishop and Wallace Stevens, but also to the poetry of their successors: John Berryman, James Merrill or Seamus Heaney. The poems are slow-moving, measured and often grippingly muted. Cole is not very much interested in allusions or intertextual effects. He prefers calling attention (in a lyrical fashion) to various modes of consciousness and articulating them in series of dense and memorable images. This may be for example seen in "Dune" (from the 2007 volume Blackbird and Wolf), one of his most important texts, a resplendent meditation consisting of six sonnet-length stanzas. At its center there is an uneasy tension between the chaos of ever-changing reality and the ordeal of the mind which attempts to discover its patterns. We have in the poem such images as those of a "dizzy/ honeycomb gleaming with amber light" or a "heap of broken things" but there is also a distinctly felt longing for artistic discipline and formal constraints (Stevens's "rage for order"). "Dune" may be interpreted as a sequence of reflections coming from the postmodern Crusoe who tries to cope with the unpredictable world and acutely feels his loneliness: the loneliness of the spirit facing the indifferent reality.

Explorations: A Journal of Language and Literature, 5 (2017), pp. 3-11 
In his introductory note to John Berryman's 77 Dream Songs (Farrar, Straus and Giroux 2014) Cole noticed: "Berryman believed that writing poems was a vocation that demanded the attention of his whole being" (xvii). Such an imperative is important and dear to Cole. To be sure, this is the poetry of nuances and details calling for attention. But it is also the poetry which reflects the experience of the whole being, and does so in a highly original, indeed unmistakable, idiom.

JACEK GUTOROW: I'd like to ask you about the beginnings. When did you discover that writing poems was something you might devote your life to?

HENRI COLE: When I was a little boy, I wrote a poem about my pet chicken Penelope. It is the first poem I remember writing. Of course, I had no thought of a life of poetry then. My life was building forts in the deep woods and exploring the nearby creeks and fields. In college, at William and Mary in Virginia, for two years I worked with the writer-in-residence, Peter Klappert, who was a passionate and kind teacher. Our class met in the living room of his college apartment, and we students loved and admired him. Peter nurtured a seed buried inside me, and coaxed it toward the light. Then I attended graduate school at Columbia University, and this set my life on the path of poetry. Forty years later, I am still a traveler on this path. I probably always knew I would not be a lawyer, civil servant, real estate broker, or military man, like my parents hoped I might be. Despite the years of uncertainty that resulted from my decision, I regard poetry as a gift in my life, and it helped me to become the person I am.

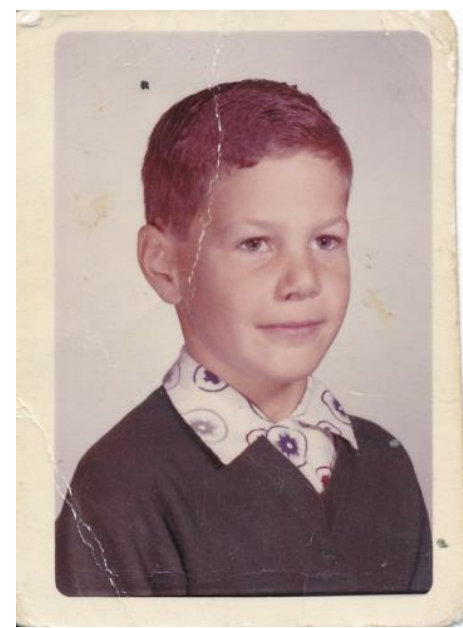

As a little boy (in 1963) 
JG: You published your first book of poems The Marble Queen (1986) when you were thirty, which makes you a rather late bloomer. Was it because of some external circumstances, like not finding a publisher or not having enough poems?

HC: Perhaps I was a late bloomer. I never thought of this before. I attended public schools and am woefully ill-read. I spend a lot of time trying to catch up. Maybe I should have waited another five to ten years to publish my first book, because now the poems show their seams. I had applied for a fellowship, and Harry Ford, who was on the selection committee, offered to publish my manuscript. He was a legendary editor, and when he took me on, I was the youngest poet on his list, which included James Merrill, Philip Levine, W. S. Merwin, and others. In-between my first book The Marble Queen and my fourth book The Visible Man, I travelled a long distance, but Harry never put his foot on the brakes. He was one of my liberators. When my first book appeared, a reviewer rightly described it as "hermetic and ornate." But there are also child-like poems that combine the mythic with the ordinary. These are my favorites.

JG: On one hand, you write in a voice that is autobiographical, transparent and immediate. On the other hand, you often turn to sustained meditative tones which make your texts somewhat elusive and impersonal. Do you see such a contradiction in your work, and if you do, is it limiting or liberating?

HC: For me, the two impulses are not contradictory; they are harmonious. Autobiography leads to thought-drift, which almost always reveals some fresh idea. The little leaps the mind makes are like a "selfyeast of spirit." The boring facts of my life may bring shame, but the images and metaphors they lead me to are like bread crumbs in a dark forest. For me, language itself is a continual source of wonder and pleasure.

JG: In one of the interviews you recollect your mid-1990s journey to Italy and your growing fascination with Italian paintings, an important stimulus which helped you move from the poetry which was basically descriptive to the one which addressed the human condition. Could you please say something more about the influence of the Italian art on your poetry?

HC: Italy was a revelation. The blood and gore of the saints and martyrs, depicted almost everywhere, sandblasted my style. My poems were too descriptive then. Too much about the flourish of language. They needed more primary emotion. And Italy made me recognize this. It's as simple as that.

JG: In a conversation with Christopher Hennessy you said: „description is often postponement of real feeling through description ... I think a poem is not just a response to the external world. It should also present the reader with a mind in action, a self in dialogue with itself." This sounds a bit Stevensian, and yet I suppose you'd raise serious reservations about the high Modernist ideal of poetry as an autonomous art?

HC: I would love to sound more Stevensian. But his distinct style would probably sink me, as with the styles of Ashbery, Plath, Glück, and Graham. A little Stevens is splendor though. I first read him as an undergraduate and then again in a graduate 
seminar with Mark Strand, an American poet sponsored by Stevens. Here is something I wrote recently for the Wallace Stevens Journal: "What strikes me about Stevens' poems is the sense that numerous ideas can be explored at once in a poem, instead of a mere plot unfolding. From Stevens, I learned that language was something like an art materialpaint, wool, steel-for creating order, and that in a poem language was the ultimate unifying experience. I respected his extreme positions, and, like him, wanted to be 'the intelligence of my soil.' I learned from Stevens that a poem could exist merely for itself, that writing poetry was a passion, not a habit, to be nourished on physical reality, and that a poem must strive to add to life something without which it seems life could not have been lived. For Stevens, a poem was not a small thing following itself into silence."

JG: Middle Earth (2003), a Pulitzer Prize finalist, was praised by critics as ,something completely new in the landscape of contemporary American poetry” (Karl Kirchwey). Did you feel, while writing the poems included in the book, that they indeed constituted a new departure for you?

HC: The poems in Middle Earth came after a long silence. I was living then alone in the foothills north of Kyoto. In a way, they are a reflection of that austere life when I was camped out in two tatami mat rooms. Austere, but luscious, too, in terms of my senses being alert to the secret vibrations of the natural world. I think I knew that my new poems were something different for me. I was still trying to rake out the descriptive flourish from my work, like raking leaves from a minimalist rock garden. The poems are inflected by my reading of the novels of Yasunari Kawabata and Kenzaburō Ōe's Nip the Bud, Shoot the Kids. This was a time of innocence in my life, and of returning to my birth place. It was also a time of transformation, like a leaf unfurling from a state of shapelessness.

JG: Could you say something more about the idea of poetic austerity which is indeed noticeable in Middle Earth? Just one example: in the poem "My Tea Ceremony," you pointed to the "plainest facts of life." Was it about a longing for a new language? Did it have impact on how you worked on your poems?

HC: I think a poet must remain true to a reality that includes astringent human experience, while also simultaneously creating an atmosphere of beauty with language. I don't want a poem's acrobatic language to push the reader away. I want the opposite. I want it to cut, rather than crochet, an ornament. There is much poetry today that accomplishes the latter, but isn't this an abdication of the poet's responsibility? I think every poem should create a small symphony of sound while also burning with a truthseeking flame. Strangely, many young poets today are wary of autobiographical feeling, and so I wonder if my idea of poetic austerity, as you call it, is outdated. But then I remember that people have died for poetry. I am trying to write in a tradition descended from Herbert to Hopkins to Heaney. I hope they are looking over my shoulder. 


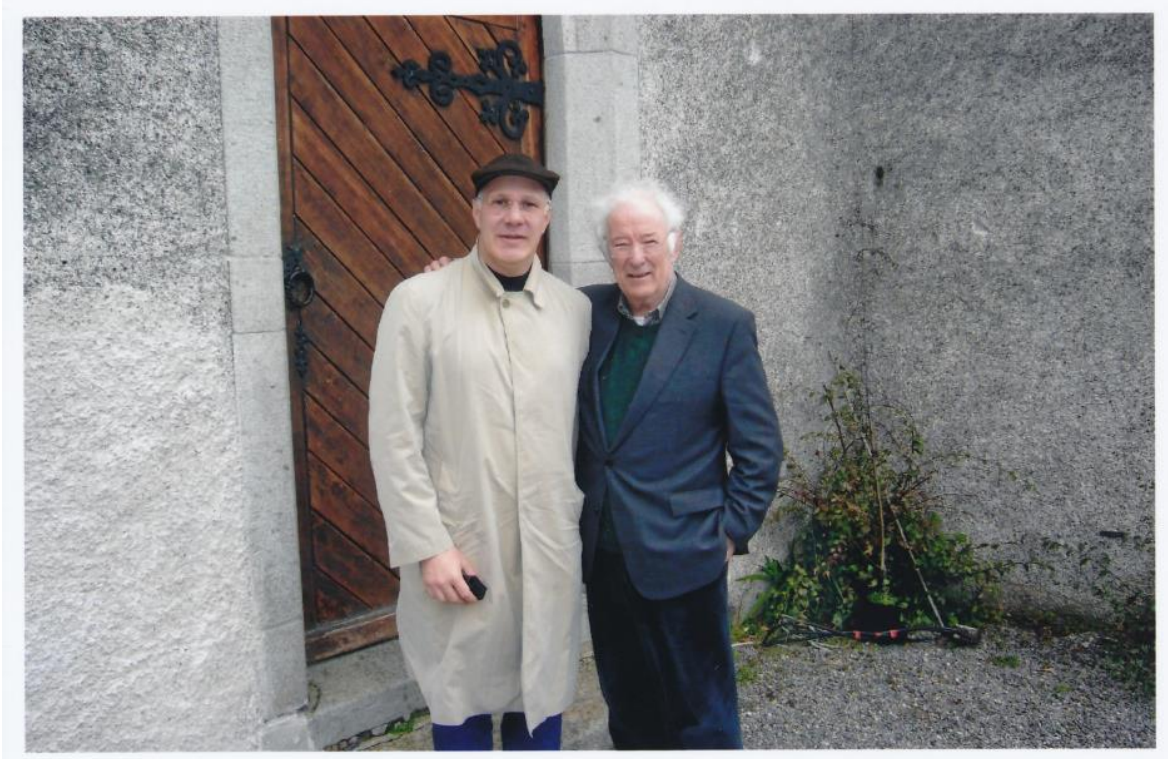

With Seamus Heaney in County Wicklow

JG: In ,Gulls" you point to a process of decreation (to borrow a word from Simone Weil): "I kicked deeper, beyond a sugar boat/ and Blake's Ulro and Beulah; beyond grief, fate;/ fingers, toes, and skin; beyond speech,/ plagues of the blood, and flowers thrown on a coffin;/ beyond Eros and the disease of incompleteness." Again, one can feel an effort to find a new beginning, something that would help you reset your vision and voice, and go back to some primary state of mind. Would it be fair to say that each of your volumes is a new starting point?

HC: Yes, what you say is true. I'm always hoping to return to a state of pre-verbal innocence and wonder. Otherwise, I suppose love and death will always dominate and be my subjects. Verse, they say, is that which reverses itself and goes around and around, but I want my poems to be both rebellious and a servant to order. Probably they are some distorted version of my normal self. I really have no set program for my poetry, except to try and succeed, if possible, with the whole insane endeavor of originality. I hope it's clear I write, in part, in order to live.

JG: I want to ask you about animals in your poems. I'm particularly interested in the poem "Twilight" with its intriguing invocation: "Come down, black bear/ I want to learn the faith of the indifferent." What kind of indifference do you have in mind? More generally, would it be fair to say that animals and a sense of animal life inspire you as a poet?

HC: Perhaps I have written too many poems about animals, as I have written too many about my mother. But we must accept our limitations and try to grow anyhow. The lines that conclude "Twilight" were not easy to write. For me, animals - like fairy tales 
and myths - are a kind of mask for the poet. What I see in them, I see also in myself. When I say, "I want to learn the faith of the indifferent," I mean simply that I want to feel less than I do, I want to be more animal, I want to NOT experience so much tenderness, fear, hunger, pain. I want to be more animal, less human. Of course, this is a terrible, paradoxical thing to yearn for, because to live is to experience feeling.

JG: In 2016 you were the main guest of the Ars Cameralis Festival in Katowice. During the festival you went to Kraków to see Wisława Szymborska's grave. I remember that once you mentioned Szymborska together with James Schuyler, and praised both poets as capable of what you called ,original sensibility." Could you please say something more about your interest in them?

HC: I was so happy to find Szymborska's grave at the Rakowicki Cemetery. Wandering around that vast city of the dead, I got lost. This was, in fact, my second visit to Kraków, and I met Szymborska on the first. We were both at a large dinner party, where I presented her with a CD of Ella Fitzgerald, which seemed to make her happy, though I know she had received a hundred others from admirers like me. Early the next day, she was leaving on vacation to a house somewhere in a forest. She smoked constantly, as did the others at the dinner table, and did not seem ill, though she would be dead within the year. It seemed to me she was impersonating an ordinary woman. The restaurant was on a rooftop overlooking the dark Kraków river, where the American artist Jenny Holzer was this night projecting Szymborska's poems onto the castle and the river. Szymborska seemed excited to see her words embodied like this, though maybe a little embarrassed, too. After she died, I had the privilege of publishing in The New Republic several translations by Claire Cavanagh of her last poems. There are many reasons to praise her work: the wry humor, the discreetness about personal details, the gentle melancholy, the stick-figure like sentences trying not to be poetry, the lack of narcissism. I love in her Nobel Lecture when she declares that to be a poet one must say repeatedly, "I do not know." I miss her poems immensely.

James Schuyler was a favorite when I was a young man. He is still my favorite New York School poet. I wish I could write a long poem as grand as his "The Chrystal Lithium" and "Hymn to Life," which are partially diary, partially mind-drift, partially weather report, and partially confession. As with Szymborska, there is no pretension in his work, no declaring, "I am the best poet, and this is my magnificent poem." It's the opposite sort of experience. I want my poems to be discreet, too, like a solo voice in a choir-discreet but distinct and memorable. 


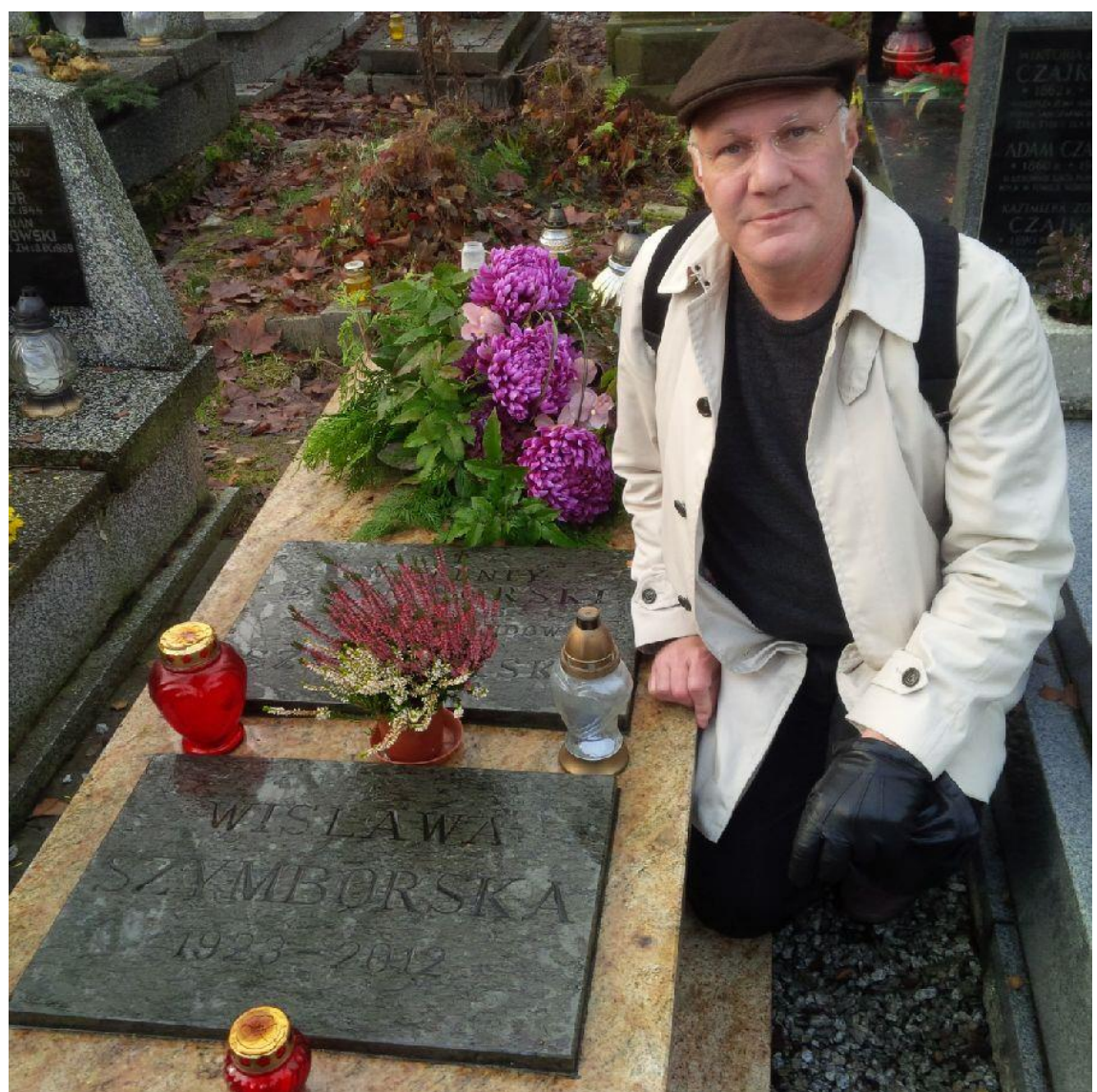

In Krakow at Wisława Szymborska’s grave (2016)

JG: Your new poems are conspicuously elegiac in tone and themes. In fact, my strongest impression of them, and of your poetry in general, is that they manage to combine meditation and elegy (like in "The Party Tent" printed below). Would you call yourself a modern elegist? Can you think of contemporary poets who helped you in being one?

HC: Perhaps all lyric poetry is elegiac, recording intense feeling long afterward in tranquility. Lamentation and praise are the two rivers that flow through elegy, and I think these rivers flow in me, too, and therefore into my poems. Two of my favorite living American poets are Frank Bidart and Louise Glück, elegists of a sort. When I was a young man, I loved James Merrill, who has fallen out of fashion now, but to me he is still a great poet. I think he is misunderstood as technically masterful but unemotional. This is what was said about Elizabeth Bishop, too. In Merrill's best poems, there is a fusion of high lyric language with ordinary conversation that I find exhilarating. Experience is poured through the ABBA quatrains that he loved and made his signature. Perhaps, too, 
all of us who lived through the AIDS epidemic were imprinted by this experience. Elegy became our song.

\section{JG: Does poetry matter these days?}

HC: Why write poetry? To capture what it is to be human, which is to say an individual voice and an individual consciousness responding to something as ephemeral as light falling on water or as monolithic as the devastation of war. Since everything else on earth seems intent to obliterate such solitary moments of being and seeing, poetry, which records and preserves them, seems to me - like air and food and love - essential and good.

\section{Henri Cole, „The Party Tent”}

The tent men arrived bearing sledgehammers and were young enough to be my sons.

After rolling out the canvas, they drove rods into the earth, heaving and grunting, with blow after blow.

When they raised the center pole, the tent went up, with tightening ropes, and I felt my heart accelerate, my heart that is nothing but a specialized nerve, which my mind feeds off.

Someday, nature's undertakers -

beetles, maggots, and bottle flies - will carry it

toward the sun. Tomorrow, after the tent is gone, a crew will remove the damaged sod, aerate what's underneath and apply a top dressing of new sandy soil. Like musical notes or forms of rock, everything will be forgotten.

This poem first appeared in The Paris Review, Issue 215 (Winter 2015) 
INTERVIEWEE'S BIO: Henri Cole was born in 1956 in Japan, and raised in Virginia, US. He received his BA at the college of William and Mary, his MA at the University of Wisconsin (Milwaukee), and his MFA at Columbia University. He debuted with The Marble Queen (1986) and has since published eight volumes: The Zoo Wheel of Knowledge (1989), The Look of Things (1995), The Visible Man (1998), Middle Earth (2003), Blackbird and Wolf (2007), Pierce the Skin: Selected Poems 1982-2007 (2010), Touch (2011) and Nothing to Declare (2015). His poems have been translated into French, Italian, Spanish and German. His awards and honors include the Kingsley Tufts Poetry Award, the Berlin Prize of the American Academy in Berlin, the Rome Prize in Literature from the Academy of Arts and Letters, and the Amy Lowell Travelling Scholarship.

E-MAIL: henricole@gmail.com

WEBSITE: www.henricole.com

INTERVIEWER'S BIO: Jacek Gutorow is Professor of American Literature at the University of Opole. His academic interests concern American and British modernism but he also writes extensively on contemporary Polish literature. He is the author of six critical books, most recently Życie $w$ rozproszonym świetle (Life in a Diffuse Light, 2016), and six books of poems. He has translated American and British poets (Wallace Stevens, John Ashbery, Charles Tomlinson, Simon Armitage, Mark Ford and others). Currently he is working on a collection of essays devoted to Anglo-American modernist poetry.

E-MAIL: gutorow(at)uni.opole.pl 